\title{
AS PULSÕES DE MORTE NO ANJO DA HISTÓRIA
}

João Galvão ${ }^{1}$

\begin{abstract}
RESUMO
Quanto às forças atuantes neste trabalho, singulares contradições em nós sobre nós mesmos frente ao outro e entremescladas na história, acreditamos que o pensamento freudiano faz magia [Magie] sem "varinha mágica" (Novalis) - com uma força constante interior ou força permanente, silenciosa, destruindo o pensamento da representação. E aqui, nos aproximamos da natureza do demônio em Freud e Walter Benjamin. Com estes estranhos rebentos presentes nestes dois pensadores, tentamos nestas pesquisas, trabalhar com alguns fragmentos deste "pensamento da diferença" aproximando-os dos escritos do primeiro romantismo e entendendo este como "pó de eflorescências" [Blütenstaub] num movimento mortuário.
\end{abstract}

Palavras-chave: Fragmentos. Pulsões [Trieb]. Inconsciente [Unbewussten]. Filosofia da Diferença.

\section{LES PULSIONS DE MORT DANS L'ANGE DE L'HISTOIRE}

\section{RÉSUMÉ}

A propos des forces agissantes dans ce travail, les contradictions singulières en nous sur nous-mêmes en face de l'autre et mélangées dans l'histoire, nous croyons que la pensée freudienne fait de la magie (Magie) sans une "baguette magique" (Novalis) - avec une force intérieure constante ou une force permanente, silencieuse, détruisant l'idée de la représentation. Et ici nous arrivons à la nature du démon dans Freud et Walter Benjamin. Avec ces étranges rejetons présents dans ces deux penseurs, nous essayons dans ces enquêtes, en collaboration avec quelques fragments de cette "pensée de la différence", les approchant des écrits du premier romantisme et compreendre comment cette "poudre d'efflorescences" [Blütenstaub] dans un mouvement mortuaire.

Mots-clés: Fragments. Pulsions [Trieb]. Inconscient [Unbewussten]. La Philosophie de la Pensée.

\footnotetext{
1 João Galvão possui doutorado em Teoria Política, pós-doutorado em Teoria Psicanalítica (UFRJ) e Filosofia (PUC); pesquisador do Grupo de pesquisa Constituição dos conceitos freudianos (UFRJ) e Walter Benjamin e a Filosofia contemporânea (UECE).
} 


\section{Noite}

Antes de mais nada é importante registrar que é a $A$ Narradora ${ }^{2}$ que deixamos dizer as cenas das narrativas que nos apresentou. [Des]conectar uma narrativa literária a uma suposta "metapsicologia" torna-se uma tarefa árdua - ainda mais se essa narrativa é atravessada por uma experiência real [intensidades e os excessos]. Aqui não existe um discurso sistematizado do nomeado "Ser" - pelo contrário, ser trans é deixar de lado o discurso deste "Ser" [ou não-ser] e se abrir materialmente para [o] prazer da vida; é deixar os desejos pulsarem na alma. O que liga ou [des]conecta Eu $=\mathrm{n}[\mathrm{ão}-] \mathrm{e}[\mathrm{u}]^{3}$ ao trans aberto é o desejo. Quando o desejo toca o corpo - nasce a abertura para o infinito - várias possibilidades entremescladas. Todo homem deveria estar aberto a esta experiência. [O] desejo de ser trans passa antes de mais nada pelo desejo da abertura do feminino entremesclado ao prazer; essa concepção criativa da narrativa refere-se ao elemento feminino que mantém sua força constante durante a obra [trabalho psíquico da alma] - é a própria criação que, ao se consumar, na experiência, dá novamente à luz e à escuridão ao criador. Os dois movimentos afluem na primeira sensação de prazer em que se misturam a cumplicidade da rua - ruas da alma. Numa daquelas ruas que Eu = n[ão-]e[u] mais tarde viria a percorrer de noite; a noite apresentando-se como signo de libertação e fuga, da mesma forma apresentada por Novalis ${ }^{4}$ em Hinos à Noite [Hymnen an die Nacht]; libertação interior pela noite e sonhos e suas criaturas da natureza - 0 mistério da noite, do sonho, da vida e/ou morte, apresentando as forças da natureza [pulsão de vida-pulsão de morte] pela experiência da narradora; figuras da natureza que nessas narrativas e fragmentos antecipam as ideias da psicanálise e da filosofia da natureza. A expressão de ser trans é expressão do prazer que [des]habita o corpo de todos. Esse desvelamento da consciência ou de um Eu privado de experiência e acorrentado pela ordem do discurso das palavras é o que impede que desejo/prazer potencializem a natureza dos homens. [Os] homens deveriam entender que faz parte da natureza o movimento que liberta seus desejos mais profundos ou o que poderíamos entender das coisas que fazem parte de um

2 DOURADO, J. \& GALVÃO JR., JC. A Narradora. São Paulo: LiberArs, 2014 [Prelo].

3 NOVALIS. Pólen: fragmentos, diálogos, monólogo. Trad. Rubens Rodrigues Torres Filho. São Paulo: lluminuras, 2009, p. 139.

${ }^{4}$ Friedrich von Hardenberg (1772-1801). 
inconsciente pulsional. O verdadeiro homem revolucionário é o homem que segue seus instintos na intensificação do uso dos prazeres. Aquele que se culpa e exerce um olhar moralizador sobre o prazer é aquele representante do rebanho que sofre com as figuras da natureza. Propomos com isso - [a] liberação [do] isso fora de uma cultura que miticamente moraliza os desejos mais profundos e intensos, que para nós, revela-se como uma coisa da natureza. A coisa [des]habita a natureza, e o nomeado "anormal" é aquele que nomeia com sua mítica violência do discurso normativo pertencente a casa do "Ser". Num movimento contrário e aberto materialmente para/no prazer das coisas [o] ser trans se plasma por intensidades pulsionais e consegue viver uma vida mais leve - mas com força e profundidade. Ser trans é um devir-animal onde a libido não faz parte de uma construção normativa da nomeada sexualidade, pelo contrário, ser trans, é todo aquele ou Aquilo que no desejo rompe com "novas" sexualidades ao encontro da libertação sexual que a cada instante fratura as formas da ordem da representação. Ser trans [Seer trans] é deixar o desejo aflorar para o uso dos prazeres. É o que vivia alguns: quando se sai de uma verdadeira ruptura, consegue-se...

\section{O demônio na alma [estado de excitação]}

O que cria ou as coisas que criam rupturas na História estão para além do discurso ou da linguagem humana que nomeia as coisas. As coisas ou linguagem das coisas na produção de fluxos e sua economia estão para além das representações e seu mítico e violento nomear das coisas. Estas coisas não são e não podem ser articuladas - mas antes de mais nada seus fluxos abrem caminhos na produção de traços de singularidade sem sujeito - o que existe é o bicho[s] intranqüilo atravessado por nervuras arqueadas. Metamorfose do[s] bicho[s] monstruoso [Ungeheuer]. Coisas estranhas [Unheimlich]. As coisas se proliferam no escuro em sua natureza - fragmentada. [O] fragmento [des]habita. $O$ que não se pode domar pelas palavras está solto fora das quatro paredes familiares da nomeada "Casa" [linguagem] e mesmo em seu interior ou entre estes dois mundos estado da alma - resiste o desejo dentro do aparelho da alma - enquanto fonte de liberdade. Na alma e formação desta alma [Seele] é introduzida [a] intensidade uma espécie de economia das forças - no efeito interior desta, na criatura do bicho 
[bichos da criatura]. Não existe "metafísica da força"5 - a força é ou não é. Existe um diálogo com o núcleo da natureza ${ }^{6}$ - este núcleo fragmentado está atravessado por excitabilidades [irritabilidade ${ }^{7}$ ]. Diante desta estranha natureza - entidades indefinidas e fragmentadas, a natureza destas excitações ou natureza de processos de excitação ou excitabilidade estão [des]ligados ao [des]prazer e ao desejo. Nesta ambivalência, aqui, inicialmente, a criatura é marcada por uma prematuração [não dispõe de aparelhos suficientes para regulação de sua excitação]. A alma atraindo a si toda excitabilidade ${ }^{8}$ [daí a estratégia do pensamento da representação em governar a Reizbarkeit] - o pensamento em Freud é que o aparelho psíquico [da alma] é efeito de captura da excitabilidade, alma aberta ao mundo exterior e ao mundo interior em relações de força - estados da alma. Esta irritabilidade não pode ser pensada pela matemática - a máxima da hostilidade da "Casa” contra este estado da alma foi rigorosamente estabelecido pelos penitentes rigorosos que acompanham a procissão dos vencedores. A respectiva irritabilidade é aniquilada pela representação religiosa ou a governação interior dos homens. ${ }^{9} \mathrm{Na}$ "Casa" não há perigo de correntes de ar. Ao sol - a "peste" aparece mais em sua face, sempre mais desestruturada do que na casa da linguagem. As coisas na natureza em sua natureza - mas há ainda outra coisa[s], de muito terrível e inquietante - silenciosa. Numa rua de mão única: se fechar [estrategicamente] por dentro mesmo em "casa" - resistir por dentro mesmo em "casa" frente o círculo dos humanos ou da linguagem humana. Na linguagem é desta forma: a "essência" lingüística das coisas é sua linguagem. ${ }^{10} \mathrm{~A}$ linguagem já é coisa - cristalizando miticamente as coisas. Das freudianas às benjaminianas, as entidades indefinidas num estado de excitação frente a exceção da narrativa discursiva do pensamento da representação. Desde a metamorfose dos animais à captura destas coisas estranhas. Palavras, palavras, palavras... O beijo do sol pode gerar larvas nas faces das criaturas humanas que habitam a nomeada "Casa". Que a palavra gelada - entra nos ossos, articulando as

${ }^{5}$ GALVÃO JR., J.C. Nietzsche no complexo [do] alemão. São Paulo: LiberArs, 2013.

6 FREUD, S. Proyecto de psicología (1895) Trad. José L. Etcheverry. In Obras Completas. Buenos Aires: Amorrortu, 2007, vol. 1, p. 327.

7 NOVALIS. Fragmentos I e II, [112]. In Pólen: fragmentos, diálogos, monólogo. Trad. Rubens Rodrigues Torres Filho. São Paulo: lluminuras, 2009, p. 143.

8 Idem, p. 144.

9 NOVALIS. A Cristandade ou a Europa. Trad. José Miranda Justo. Lisboa: Antígona, 2006, p. 30, 37, 57.

${ }^{10}$ BENJAMIN, W. Sur le langage en général et sur le langage humain (1916). Traduit Maurice de Gandillac. In Oeuvres I, Paris: Gallimard, 2000, p. 145. 
coisas. Neutra. Ao articular - neutraliza as coisas eliminando suas forças. Não se engane nos seus cálculos: aquela Palavra era tão visível que se podia distinguir até no meio da escuridão? Ficaram acordados tagarelando na Floresta em voz alta até seus crepúsculos. Finitude da criatura humana - nomeado humano [criatura hostil]. Humanismo. Inconfundível pastor pela linguagem. O Pastor recolhe o rebanho e a alma como o surgimento do humano no aberto - aí não há nenhuma especulação sobre a "metafísica" da alma? "Metafísica" [d]O aberto. O perigo é ameaçador onde as alianças de uma "estrutura" são constituídas pelas identificações dos seus membros uns com os outros na salvação daquele lugar aonde chegou numa escuta obediente. Mas as estranhas entidades não vêem esse "ser" em parte alguma, não ouve a sua palavra nem a sua voz. Não há identificação. Seus estranhos fluxos acabam por romper e fraturar a nomeada estrutura num estado de excitação. Têm o demônio na alma - possuído[s] pelo[s] demônio[s]. Estranho e não estranho [ “ser" ou “não-ser"] - posição estratégica. Silenciosa metamorfose das coisas frente às

palavras. É preciso resistir de dentro da alma. Do deserto - expulsos retornam à "Casa" intensificando [o] estado de excitação das coisas num combate entre os demônios.

\section{Companheiro diabólico}

O movimento da libido não capturada por dispositivos [político e teológicopolítico] numa constante dos fluxos e sua expressão, não é ligado em significantes ou por virtude do Espírito Santo. A criatura nomeada de sujeito na modernidade atravessada pelo discurso humanista não repousa sua constante insistência num jogo de significantes. O caráter do jogo está para além deste discurso que deseja estruturar as coisas no plano extensivo. O desejo aqui - não somente vive e habita a extensividade das coisas; um certo tipo de ditadura do significante é inseparável de uma certa civilização e sua peste emocional. Na governamentalidade - o trabalho cultural de territorialização significante do espaço das almas frente a esta criatura, põe em jogo esta extensividade no combate a desterritorialização das expressões. Suas cadeias significantes alienam num imenso maquinário cultural, representacional e técnico. O reflexo do espelho passa ser reflexo humano. Toda a libido é então capturada, subjetivada - [re]cristianizada - em função das exigências da economia e teologia dos fluxos capitalistas. Qualquer estádio libidinal é uma estrutura patológica ou patologizada. Existe uma reificação dos fluxos extensivos. 
Todas as intensidades pulsionais concorrendo à formalização da ordem do discurso devem se alinhar - a pulsão deve ter seu passe pela linguagem humana - a pulsão deve ser articulada ao "ser". Guerra de espaços na alma [Seele]. Territorializandodesterritorializando - culturalmente governam-se as figuras da natureza. A guerra por estes espaços da alma tem seu passe na captura do jogo da criança - desde a tenra idade - quando a criatura é marcada por uma prematuração [ou estado de uma criança prematura]. Ou seja: a criança não dispõe de aparelhos suficientes para regulação de sua excitação; seu aparelho da alma não está ainda completo e atravessado de espectros. ${ }^{11} \mathrm{O}$ resto é silêncio. Esta criatura é caracterizada pela excitabilidade [irritabilidade]. O fascismo presente no alerta do Anti-Édipo seria uma destas formas de representação frente à excitabilidade que deseja abertura. Os domínios religiosos, filosóficos e científicos eliminam este jogo que estimula o florescimento das coisas, frente a este extermínio e sua impossibilidade quando as partículas renovam em constância e disseminam contaminando as coisas libertadas pelo pólen. Entremescladas, as coisas estão aí. O pensamento contido nos fragmentos de $1895^{12}$ floresceu nas teorias da psicanálise freudiana. $A$ vida floresce e morre já morrendo - no florescer disseminando o pólen já se está murchando num processo de mortificação - imanência da morte na vida; como a vida encontra na morte sua mais diferenciada figura. Efeitos da finitude. Mas, talvez, o Pastor do “ser" seja metafísico porque pensa a vida de um lado e a morte de outro lado; de uma ontologia vitalista para uma ontologia mortalista onde o total pensamento a respeito do sentido abrangente do nomeado "ser" repete o mesmo [inconsciente] de uma tradição metafísica que em sua orientação teológica pensa extensivamente ter superado a morte de [D]eus. A massa [ou "multidão"] quer proteção. A Filosofia não é tão rosa - muito menos o discurso que se arroga científico. Em sua radicalidade “O Nascimento da clínica” - dá legitimidade à psicanálise: como pensador, Foucault, na dor dos vencidos. Poderíamos falar de uma história a contrapelo - uma moldura teórica que questiona a tradição e patrimônio cultural dos vencedores. Trágico da finitude presente na psicanálise e no drama barroco. Patrimônio cultural aliançado a submissão[sujeição significante] e ao formalismo transcendente dos campos significantes que não passam de um momento cultural - humanista.

\footnotetext{
${ }^{11}$ FREUD, S. Carta 52 (1896). Fragmentos de la correspondencia con Fliess. Trad. José L. Etcheverry. In Obras Completas. Buenos Aires: Amorrortu, 2007, vol. 1, p. 277.

${ }^{12}$ FREUD, S. Proyecto de psicología (1895) Trad. José L. Etcheverry. In Obras Completas. Buenos Aires: Amorrortu, 2007, vol. 1, p. 323 - 446.
} 
Portanto, não se trata de reportar apenas a obra à intimidade, mas de dissolver o logro da intimidade significante. A forma discursiva da psicanálise tenta representar todas as coisas numa complexidade na estrutura da linguagem humana laconizando a coisa em ato, operação que totaliza uma visão de mundo - "Matemática pura é religião" ou “Quem pega num Livro de matemática sem devoção e não o lê como palavra de Deus, esse não o entende". ${ }^{13}$ A coisa instintual se esgotará inteiramente na sintaxe inteligível do Significante. Tal modo de falar revela aparentemente o sentimento de que se trata de alguém de "Casa" frente ao estrangeiro potencialmente esquizo [“Ouçam o louco!"’14]. Sonoridade de voz, dom de falar, superioridade, saúde, perseverança, presença de espírito, conhecimento dos nomeados humanos, visão geral do mundo - [o] bicho[s] torna-se tão diferente e nessa diferença tão perigoso para o outro com face [não o outro do outro], que este outro, comungando destas qualidades, calcula antecipadamente como esmagar o bicho sob os pés. Mas o que é vivo não comporta o cálculo - as intensidades não são exatas, por isso, devem ser eliminadas pelo discurso do nomeado "ser" [linguagem humana]. Muitos fornos crematórios serão necessários para o discurso filosófico conseguir exterminar o estranho parasitismo da psicanálise e do barroco. Quando a psicanálise tenta revelar as forças ocultas e seus demônios, torna-se estranha. ${ }^{15}$ Como forma de defesa frente à nomeada "Casa" a criatura desaprende a falar ou partilhar desta linguagem humana - a palavra lhe é interditada. ${ }^{16}$ Mas neste movimento aleatório de partículas num fluído não há fala - mas bicho[s]. Vida e destrutividade se fazem presente no instante do agora. Não há voz nem face apenas excitabilidades entremescladas. O instante das coisas não tem seu passe pela habitação do [auto]nomeado "ser". Mas, a problemática da excitabilidade e seu controle não passam longe da chamada política bioteológica a repetir o mesmo num modelo lingüístico humano crente de si. Espicaçando a criatura, o companheiro diabólico impede que aquela soçobre em integral repouso. Um mundo mágico e silencioso das coisas da natureza trabalha a cada instante num ruído pulsional - o barroquismo incontrolado das coisas trabalha nos fluxos a cada instante, criando novos espaços na abertura e rachadura das paredes desta nomeada "Casa”. As

\footnotetext{
${ }^{13}$ NOVALIS. Selecção dos fragmentos e estudos de 1799-1800. In A Cristandade ou a Europa. Trad. José Miranda Justo. Lisboa: Antígona, 2006, p. 85, 86.

14 The Prophet's song (1975).

${ }^{15}$ FREUD, S. Lo ominoso (1919). Trad. José L. Etcheverry. In Obras Completas. Buenos Aires: Amorrortu, 2007, vol. 17, p. 243.

${ }^{16}$ KAFKA, F. Carta ao pai. Trad. Modesto Carone. São Paulo: Companhia das Letras, 1997, p. 21.
} 
coisas que disseminam o polínico são os bichos e o vento - o[s] bicho[s] e o vento como polenizadores.

\section{La Destruction comme cause du devenir}

Verdadeiro soldado profissional, que infesta o campo de certa cultura menor, o inseto daninho, perverso, bicho[s] suga o sangue [des]conservando a morte na vida - tornando a vida e a morte mais leve - parasitando ${ }^{17}$ o discurso do nomeado "ser" ou de uma "cultura européia". Nesta cultura [parasitada], o estatuto filosófico do homem, para além do ser do homem como objeto de saber metafísico e saber positivo, num uso de fidelidade e obediência incondicional, a resistência da experiência de singularidades no inconsciente como descentramento desta criatura é polenizada pelos bichos e o vento. No trágico barroco da finitude a criatura encontra nas figuras da natureza seu romantismo primeiro. "Descrever seres humanos tem sido impossível até agora, porque não se tem consciência do que é um ser humano (...)". ${ }^{18}$ Encontramos apenas as coisas finitas e entremescladas. Nestas coisas diversas e singulares as partículas habitam o ar - são movimentadas pelo vento. Coisas diferentes como o "ser" no ar, no movimento do vento representam para além do pensamento da representação, intensidades intemporais rememoradas pelo ato da criatura presente em instante. Uma rua de mão única para não repetir o mesmo, conhecido e nomeado logos grego. [Des] habita no ar. Estar no ar disseminando pólen com o vento. [O] pólen no séc. XX são as cinzas no ar ser[es] no ar - espectrais que contaminam e ainda parasitam uma cultura. Um gosto de cinza voa no ar - exalando-se da lareira da Casa; eis o tempo dos assassinos, um Ser de Beleza de alto porte. ${ }^{19}$ Espectros [spectres] ainda rondam a cultura européia. “...vejo espectros novos rolando através da espessa e eterna fumaça de carvão..." ${ }^{20}$ A psicanálise e o barroco habitam no ar - disseminando Pólen. Cinzas. Aqui, a dor dos vencidos se faz presente no instante histórico entre memória e contra-história [história a contrapelo] - a vida psíquica a partir da ideia de história finitude. As partículas do pólen que habitam o ar desta cultura encontram-se no embate ou encontro impetuoso entre pulsão de vida e pulsão de morte inscrevendo-

\footnotetext{
17 Idem.

${ }^{18}$ NOVALIS. Pólen / Observações entremescladas [108, 119]. In Pólen: fragmentos, diálogos, monólogo. Trad. Rubens Rodrigues Torres Filho. São Paulo: lluminuras, 2009, p. 98 - 99.

${ }^{19}$ RIMBAUD, A. Illuminations. Paris: Gallimard, 1999, p. 18, 26, 28.

${ }^{20}$ Idem, p. 32.
} 
se num solo de uma criatura da finitude. As coisas finitas e entremescladas de morte na vida exercem uma função conectora: fazem aumentar as conexões do desejo no campo de imanência - aqui, o desejo mais erótico produz um investimento silencioso entremesclado com sua destrutividade interna. Há uma relação de imanência entre pulsões e inconsciente [inconsciente pulsional] - intensidades que fogem da domesticação do nomeado sujeito, permanecendo por uma força constante com [o] bicho[s] da criatura e conectando-a às silenciosas forças destrutivas da natureza e sua pulsão erótica. Existe um movimento dos impulsos destrutivos inconscientes contidos na própria vida que cria abertura[s] na vida; a cada instante silenciosamente seus instintuais pulsionais de morte [des]conectam as forças instintuais na/da vida. Se por um lado, as manifestações instintivas das pulsões de morte são independentes do libidinal erótico da vida, estar em relações de forças pulsionais autônomas não significa que estas coisas da natureza não estejam entremescladas entre elas. As coisas se irritam com as coisas. A natural pulsão de caráter destrutivo da criatura deriva da natural pulsão de morte que se move ao lado das pulsões de vida. Da mesma forma as criaturas reúnem-se libidinalmente e [des]ligadas umas as outras, seus movimentos instintuais pulsionais a cada instante entremesclam-se entre si diante da natureza. Suas obscuras e silenciosas coisas instintualmente resistem frente à nomeada civilização; seu caráter autônomo ${ }^{21}$ e ao mesmo tempo entremesclado - ambivalentemente trabalham com vida e morte e morte na vida. A força da natureza de criar e irromper para morte e com a abertura da morte. A dimensão da criatividade se faz presente na literatura psicanalítica e seu trágico barroco da finitude, rememorando seus dias de 1912 com Sabina Spielrein em A Destruição como causa do devir [Die Destruktion als Ursache des werdens $^{22}$ ] - tentativa de compreender as experiências dolorosas das forças que embelezam e ao mesmo tempo destroem tudo, perigo desconhecido vindo de dentro; o instintual pulsional sexual sendo contraditório em si mesmo - luta pela vida e pela morte frente a um impulso destrutivo. Os bichos da criatura não podem dizer o que querem - estas coisas são mudas; a luta da vida e suas pulsões de morte impulsionam num devir as coisas dentro do bicho[s] da criatura. Talvez a sombra de

\footnotetext{
${ }^{21}$ FREUD, S. El Malestar en la cultura (1929). Trad. José L. Etcheverry. In Obras Completas. Buenos Aires: Amorrortu, 2007, vol. 21, p. 113.

${ }^{22}$ SPIELREIN, S. La Destruction comme cause du devenir (1912) Trad. Pierre Rusch. In Sabina Spielrein: entre Freud et Jung. Paris: Aubier, 1981, p. 213 - 262 [Die Destruktion als Ursache des werdens. trad. livre de Renata Udler Cromberg - USP].
} 
morte entremesclada com um intenso pulsional erótico em devir tenha trabalhado de forma tal, impressões e experiências acumuladas nas forças demoníacas ou esquizo de Spielrein. Talvez estas forças se apresentem como mais “junguianas” do que na realidade são. O pensamento não parte de imagens, estas que são imagens de pensamento - mas Sabina Spielrein está para além da pura imago cristalizada, vai de encontro ao caráter destrutivo das pulsões de morte ou das pulsações inconscientes de morte. O para além de si mesmo que a si mesmo cria e a si mesmo destrói, a criatura em sua finitude está aberta a um perigo outro, ${ }^{23}$ natural, silencioso - obscuro. Mas [o] obscuro aqui, não é o escuro do universo. O escuro é o escuro da criatura em suas pulsões de morte. Silêncio escuro das pulsões de morte - são experiências. Nesta sombra de morte - rememorar ou a prática da presentificação anamnésica [Eingedenken ${ }^{24}$ ] é abrir a dor dos outros na História - força de resistência na rememoração do passado dos mortos. Tempo passado experienciado na rememoração dos mortos, estranha à vida e candidata à morte - não há discrepância entre seu pensamento e suas ações, como também à diversidade de seus impulsos de desejo. Os mesmos bichos esquizos que trabalham em caráter destrutivo rompendo com a vida e conectando com a vida tem suas passagens pelo retorno sexual do estranho cheiro erótico na criatura civilizada. O [des]prazer é um hóspede permanente assombrado por suas pulsões de destruição inconsciente. Aqui, o além do bicho[s] segue o cheiro do erótico e instantes do caráter destrutivo. $\mathrm{Na}$ repressão orgânica e repressão cultural [moral] habita o governo dos vivos -o nomeado "poder soberano" e a refinada biopolítica. Com a perda economicamente não satisfeita destes instintuais pulsionais ou da natureza frente a sua primeira repressão, os bichos da criatura passam a ser domesticados pela segunda repressão cultural habitada por estas técnicas. A vida passa a ser "humana". Os que habitam a "casa" tratam da "palavra", porém, mostra-se que a "palavra" e o que ela nomeia é que tratam dos que habitam esta morada. A coisa nomeada em cada "palavra". As palavras devem experimentar seu poder de nomeação e conjunção. Ser fiel ao ser da "palavra"; é a partir da fidelidade já dominante na unidade da "palavra". Mas [o] obscuro é sempre mais e outra coisa estranha: alguma coisa não tem seu passe pelo nomear, arrebenta de forma independente -

\footnotetext{
${ }^{23}$ Idem.

${ }^{24}$ BENJAMIN, W. Sur le concept d'histoire [Appendice B] (1940). Traduit Maurice de Gandillac. In Oeuvres III, Paris: Gallimard, 2000, p. 443.
} 
[o] bicho[s] atravessado de excitabilidade; entremescladas, as excitabilidades dos bichos fazem com que a criatura não renuncie ao seu caráter instintual. A matilha de suas intensidades continua a pulsar enquanto as forças silenciosas de morte estiverem presentes na vida. Na natureza do homem, criatura da natureza, as coisas estão entremescladas de uma vida sexual livre [antes de seu porte ereto] e pulsões de destruição. Nesta criatura da natureza, sua sexualidade vem de fora para dentro entremesclando-se com suas pulsões de morte que vem de dentro para fora. A natureza dos bichos já trás a diferença em si; enquanto a dita "civilização" ["cultura"] impõe à criatura, sacrifícios à sua vida sexual e sua força erótica e a seu caráter destrutivo. ${ }^{25}$ Em suas conexões - os bichos criam diferenciais mínimos que as coisas colocam e que se inscrevem entre outras criando rupturas no campo da repetição do mesmo. As coisas dos bichos que não respondem e resistem à nomeada "estrutura" mítica introduzem uma diferencialidade na esfera sacralizada do mesmo. Do silencioso movimento das coisas dos bichos, sua inexorável natural finitude de morte a cada instante aparece em ato diante do desejo das mais obscuras forças. [O] bicho[s] com todo terror aparece em ato. A batida e o silencioso ritmo já é de pulsão de morte [“chuuunc"26]. As vibrações irregulares de um som nascido do silêncio fazem com que a linguagem das coisas floresça com a morte para a liberdade. $O$ amanhã nunca se sabe - é indeterminado. As coisas dos bichos podem ver o significado de dentro [interior] e ouvir a cor de seus sonhos. A linguagem não é significante - nasce do silêncio das coisas. No começo das coisas não está a "Palavra" ou sua "decisão" do "Verbum", segundo a estrutura do Evangelho de São João e seus discípulos falantes. ${ }^{27}$ Numa das passagens do Fausto de Goethe: era no início - a Ação[!] [Ato]. ${ }^{28}$ Seu "pacto" [aposta] com o demônio é movimentado neste silêncio de morte na vida - criando coisas menores [diferenciais mínimos] e por isso, ainda mais política, na sua própria linguagem, diferenciais mínimos que com seus estilhaços movem o eterno retorno conectando este com seus bichos. Na criatura - a alma é entregue ao demônio [o psíquico é

\footnotetext{
${ }^{25}$ FREUD, S. El Malestar en la cultura (1929). Trad. José L. Etcheverry. In Obras Completas. Buenos Aires: Amorrortu, 2007, vol. 21, p. 111.

${ }^{26}$ Come together (1969).

${ }^{27}$ Fausto prepara-se para traduzir o Evangelho de João. No original, a expressão grega Logos [Verbum, na Vulgata] vem traduzida por Wort, "Palavra", em consonância com a tradução de Lutero.

${ }^{28}$ GOETHE, J.W. Fausto: uma tragédia. Trad. Jenny Klabin Segall. São Paulo: Ed. 34, 2011, p. 112 [Mefistófeles dá a entender que, sob o disfarce de cão, ouvira o pouco apreço de Fausto, ao traduzir o início do Evangelho de João].
} 
entregue às intensidades]. E aqui, nos aproximamos na natureza do demônio em Freud. "O demônio tem muitas coisas a oferecer (...)" ${ }^{\text {"29 }} \mathrm{A}[\mathrm{s}]$ criatura[s] da natureza permeada de Energia e parte da Energia - "Que sempre o Mal pretende e que o Bem sempre cria". ${ }^{30}$ Essa aposta, assinada com o próprio sangue da criatura, pode estender-se por alguns anos; entremesclados frente à natureza e seus instintos de criação e morte na criação, que cria e fratura silenciosamente. O desejo que rompe nasce do silêncio, não é apanhado na rede de representações e não é neutralizado por um significante no campo social - os bichos na criatura são atravessados por conexões e [des]ligações instintuais pulsionais. As pulsões e instintos são tramados - como nas mórbidas esculturas de Camille Claudel; organicidade contaminada, destruída pelas velhas formas informes mas ainda parasitadas pela erótica da vida. O desejo pulsa no interior das coisas - desejo que na criatura é o mesmo desejo que no bicho[s]. [O] bicho[s] como "entidade psicanalítica" (Bruno Cava) - [o] animal que impõe sua presença; [o] bicho[s], a mulher e as crianças - água corrente e luzes que tremem no terror do escuro. O leão teria sido domesticado ${ }^{31}$ A estrutura essencial dos discípulos que comungam a "palavra" tentam perceber extensivamente pela linguagem humana as imensas marcas de unhas deixadas pelo bicho[s] - referência a Bellérophon [ $\beta \varepsilon \lambda \lambda \varepsilon \rho \circ \varphi \tilde{\omega} v ; \beta \varepsilon \lambda \lambda \varepsilon \rho \circ \varphi \operatorname{vovt\eta }^{32}$ ], caçador de animais. De Razão dá-lhe o nome, e a usa, afinal, pra ser feroz mais que todo bicho[s]. Retorno ao mesmo daquilo que torna possível e suporta a representação de um mundo humano ordenado e articulado. O caçador, representante da "palavra", fala que as marcas são recentes, indicando pela palavra falada que dois imensos lobos e seus filhotes corriam no incêndio. Frente a "palavra" representacional do caçador, a morte do lobo [La mort du loup] se faz presente para estes representantes. ${ }^{33}$ Mas só o silêncio é silencioso. [O] bicho[s] com sua alma trabalha para realizar infinitas ligações - ligações da [des]ordem do silêncio. Essa infinitude não é uma infinitude da continuidade, mas uma infinitude da conexão. Hölderlin proclamou essa profundidade das coisas e suas forças expressando esta

\footnotetext{
${ }^{29}$ FREUD, S. Una neurosis demoníaca en el siglo XVII (1922). Trad. José L. Etcheverry. In Obras Completas. Buenos Aires: Amorrortu, 2007, vol. 19, p. 81.

${ }^{30}$ GOETHE, Fausto: uma tragédia, p. 118.

${ }^{31}$ CAVA, B. A Revolta dos leões marinhos. In Quadrado dos loucos - prosa, crítica, crueldade e desejo. www.quadradodosloucos.com.br

${ }^{32}$ GALVÃO JR., J.C. Sobre a "exceção humana» - Carta a Lacan, Jung, Schmitt... São Paulo: Liber Ars, 2012.

${ }^{33}$ VIGNY, A. A Morte do lobo. In Poetas franceses do século XIX. Trad. José Lino Grünewald. Rio de Janeiro: Nova Fronteira, 1991, p. 18 - 23.
} 
conexão interna [connexion interne extrêmement fort ${ }^{34}$ ]: conectar infinitamente na finitude da criatura. A natureza começa a se manifestar e as coisas dos bichos começam a aparecer. "Da terra, da água, e mais dos ares / Brotam os germes aos milhares a desdobrar-se / Várias coisas irrompem e crescem / No seco, frio, úmido, quente! ....35 $\mathrm{Na}$ natureza - [0] bicho[s] tem de aparecer em ato. Em sua silenciosidade, [o] bicho[s] sussurra: "o caos reina",36 - forças obscuras e demoníacas atuando - o pulsional se faz presente - os filhos do lobo em silêncio brincam ruidosamente. Um uivo instintual das pulsões alerta dos perigos do incêndio na natureza e da tentativa de extermínio do estranho bicho[s] na criatura. Se olharmos ao nosso redor e interiormente - será que encontramos [0] "caos"? Será que isto é oposto à [des]ordem da [in]governabilidade? Ou será que a "palavra" humana continua a nomear o bicho[s]? Natureza exterminada à natureza profundamente moral da humanidade. ${ }^{37}$ As forças mais obscuras dos instintuais pulsionais de morte fazem parte desta cena - magismus. $O$ eterno instintual pulsional erótico da vida retorna na luta com seu não menos imortal adversário: as pulsões de morte - silenciosas e mágicas. Pela magia - vida e morte permanecem entremescladas. Mas este entremesclamento ainda permanece reservado aos historiadores da magia e sua ação.

\section{É um demônio de ação}

A magia não é um conceito. É como se um fragmento solto, livre e aberto se conectasse a outro fragmento e este a outro fragmento e estes se conectassem entre eles com outros numa infinita ligação. Aí residiria a magia das coisas e sua magia - a magia de resistir. São trabalhos que se fazem com rupturas e ligações diante deste conectar-se - como num poema. Lembremos de Faustus, que diante de sua experiência com o terrível monstro [Ungeheuer], ainda sob a forma de seu cão, tenta enfrentar num primeiro momento este monstro perverso com uma fórmula mágica, fazendo este ser oculto no animal revelar seu verdadeiro aspecto. Os versos mágicos que pronuncia referem-se aos espíritos dos quatro elementos Salamandra: espírito do Fogo; Ondina: espírito da Água; Silfo [ou a forma feminina

\footnotetext{
${ }^{34}$ BENJAMIN, W. Le concept de critique esthétique dans le romantisme allemand (1920). Trad. Philippe Lacoue-Labarthe et Anne-Marie Lang. Paris: Flammarion, 2008, p. 58.

${ }_{35}^{35}$ GOETHE, J.W. Fausto: uma tragédia. Trad. Jenny Klabin Segall. São Paulo: Ed. 34, 2011, p. 121.

${ }^{36}$ Antichrist (2009).

${ }^{37}$ FREUD, S. El Malestar en la cultura (1929). Trad. José L. Etcheverry. In Obras Completas. Buenos Aires: Amorrortu, 2007, vol. 21, p. 116.
} 
Sílfide]: espírito do Ar; Gnomo: espírito da Terra. Usa o verso: "Salamandra se abrase, Ondina se retorça, Silfo se encase, Gnomo use força" ${ }^{38}$, enquanto a neblina se dissolve e o Ungeheuer aparece como o demônio Mefistófeles. O enigma da Energia[s], parte destruidora, parte criadora, perece na natureza com seu corpo erógeno pulsional a todo instante marcado entre o movimento prazer-desprazer. Esta infinitude na sombra da finitude realizada do conectar acontece inextensivamente como resistência e movimento no acontecimento da alma. Umas coisas se tornam irritadas com as outras coisas [pulsão de vida com pulsão de morte]. Da natureza - impulsos instintuais silenciosos que partem da escuridão e é com os corpos que perecem em sua finitude - drama da criatura. "O nome libido pode aplicar-se novamente às manifestações da força de Eros, a fim de separá-las da energia da pulsão de morte." ${ }^{39}$ Mas neste drama, qual o nome da energia da pulsão de morte? Não tem nome, não pode ser nomeada. É uma coisa[s] obscura [ina] habita o interior e o silêncio ruidoso do pântano. Vai vivendo como um crocodilo. Um bicho[s] antigo - algo que torna uma coisa misteriosa, sendo que tornar misteriosa esta ciência natural é retirá-la do âmbito empobrecedor do saber positivo estritamente objetivo. Na planície interior inundada de energias das pulsões de vida e das pulsões de morte [des]habita o bicho[s]. Das figuras da natureza, profundidade instintual, as coisas retornam à sua força de destruição; criando e forjando diferenças [para além do discurso da metafísica da diferença]. No mundo da natureza [coisas não nomeadas] não há nomes, mas bicho[s] - Energias em suas retornanças diferenciais. Linguagem como algo puro [das coisas], trabalhando num terror ou num movimento repetido; como se a linguagem se tornasse bicho[s]. Trabalho das coisas ou da linguagem das coisas [pulsão sem representação] que coloca [os] bichos da criatura num movimento de terror como algo invisível e silencioso criando as aberturas no instante da História. Trata-se [d]o aberto material e não da "metafísica" [d]o aberto. Estas forças intensivas que são desencadeadas não remetem para uma lei determinada do discurso ou linguagem humana como linguagem fônica representacional. Pelo contrário: estas forças demoníacas destroem com suas forças mais selvagens - puramente [divinamente] - com a cadeia de significantes representacionais. Impulsos instintuais inerentes à própria

\footnotetext{
${ }^{38}$ GOETHE, J.W. Fausto: uma tragédia. Trad. Jenny Klabin Segall. São Paulo: Ed. 34, 2011, p. 115.

${ }^{39}$ FREUD, S. El Malestar en la cultura (1929). Trad. José L. Etcheverry. In Obras Completas. Buenos Aires: Amorrortu, 2007, vol. 21, p. 117.
} 
natureza dos instintos pulsionais. Algo ou alguma coisa indeterminada não vai ser domesticada. Não há domesticação dos resíduos. Os impulsos instintuais mais profundos se tornam estranhos [estranho à "Casa" da linguagem]. Mágico confronto de forças da pura intensidade radicalizada em sua destrutividade; forças de um inconsciente pulsional operando silenciosamente numa intensidade do trágico [intensidade barroca]; metamorfoseando-se ou tornando diferente os instintos em si; retornando a morte em si; e mesmo assim, toda a vida é um processo de destruição. Marginalidade da magia; ambivalência marginal; fragmentos marginais; o caráter destrutivo presente no fragmento; marginalidade da própria coisa e das coisas [o fato da vida já não habitar o todo] - coisas mágicas: as crianças montadas nos mais terríveis animais / correndo no movimento de cavalos azuis [vida] e negros [morte]. ${ }^{40}$ A coisa marginal fragmentária que lança com seus estilhaços suspeição sobre as formas de totalização gerando destrutivos que não mais habitamos. [Des]habitar e [Ina]bitar. Fragmentum pulsional - estilhaços [pedaços de qualquer coisa], resultados de uma destruição pura. Estes estilhaços pulsionais numa relação de forças repetem o diferente criando uma abertura material [o aberto não é discurso]. Intensidade barroca fraturando a figuração, representação, símbolos e imagens arcaicas, o bárbaro da alma que faz explodir o pensamento da representação e as intensidades das forças representadas. O que está em jogo é a fragmentação psíquica. Estas intensidades definem como a força se comporta forças internas numa relação de forças; este poder muda a cada instante no interior de estilhaços pulsionais para a destrutividade do mundo das coisas em sua forma política [nomeada] ou de um animal nomeado "político" ["poder soberano" e "bipolítica" não domesticam (o) instintual pulsional demoníaco destrutivo]; seus fragmentos estilhaçados e partículas de substância viva polenizadas e dispersadas ${ }^{41}$ irrompem com formas e coisas nomeadas num jogo de resistências. Irrupções de um inconsciente pulsátil rompem com as acomodações do mundo das coisas nomeadas: “...é um Demônio de ação, ou Demônio de combate”. ${ }^{42}$ Como apresenta Klee em sua Flor sobre o rochedo ${ }^{43}$, estes traços despertam ecos trágicos: manchas flutuam sobre um fundo crepuscular. É um olhar lançado sobre a magia da natureza

\footnotetext{
${ }^{40}$ RIMBAUD, A. Illuminations. Paris: Gallimard, 1999, p. 33.

${ }^{41}$ FREUD, S. Más allá del principio de placer (1920). Trad. José L. Etcheverry. In Obras Completas. Buenos Aires: Amorrortu, 2008, vol. 18, p. 57.

${ }^{42}$ BAUDELAIRE. C. Espanquemos os pobres! In Poesia e prosa. Trad. Aurélio Buarque de Holanda Ferreira. Rio de Janeiro: Nova Aguilar, 1995, p. 338.

${ }^{43}$ Flor sobre o rochedo, 1940. Kunstmuseum, Berna. Paul Klee.
} 
criadora. Mas aqui, [a] flor adquire a dimensão de uma "botânica carnívora" - flor carnívora - onde o caos da animalidade $d o[s]$ bicho[s] já está apresentando-se no movimento dessas escuras partículas sobre o rochedo - fraturando-o. A magia das coisas da natureza não se explica - são demônios inscritos no corpo e na alma. [A] Energia - [ela] é. O nomeado “ser" era. E o imprevisível está aí. Sua magia. As freudianas \& benjaminianas carregadas de energias \& alegorias contrastam na sua magia colorida com o frio e neutro pensamento da "Casa". Quando passa a neblina, não Ihes são essenciais as figuras que elas formam? Ou suas imagens? Lhes são indiferentes. Mas sim, a névoa elástica, que são compridas pelo impacto constante do vento, levadas adiante desde o início, disseminadas e também rompidas: esta é sua natureza - [a] magia das forças [força natural]. Nesta silenciosa linguagem das coisas - seu caráter mágico e demoníaco. Forças pulsionais ou da existência de uma modalidade de pulsão sem representação. ${ }^{44}$ É a magia das forças da natureza. Não há explicação do Ocidente para a magia.

\section{[O] Aberto}

Retornando à Freud com as coisas que Walter Benjamin em seus últimos escritos de 1939-1940 tentou resgatar: a radicalidade política das pulsões [intensidades] expressando-se num pensamento da prática subalterna da dor dos vencidos. Freud não precisava de reconhecimentos na esfera do político, mas existe um registro muito forte por parte de Benjamin, nos últimos anos em vida: das pulsões na história [estado de excitação mais real, estado de exceção]; caráter de originalidade presente nos desdobramentos de seu trabalho ou em alguns de seus fragmentos: "O despertar do sexo", onde Benjamin surpreende-se com o despertar da pulsão sexual, de uma pulsão desperta vinculada a uma ética da judeidade; ${ }^{45}$ em "Filatelia", escrevendo sobre selos, tecidos celulares gráficos onde tudo pulula em confusão, onde neles a vida teria sempre uma marca da decomposição da morte [destruição/ finitude], mostrando que é composta de matéria já morta ${ }^{46}$ - radicalidade da finitude da criatura; ou mesmo em "O Caráter destrutivo" que cria espaço e é

\footnotetext{
${ }^{44}$ BIRMAN, J. Sujeito e estilo em psicanálise: sobre o indeterminismo da pulsão no discurso freudiano. In As Pulsões. São Paulo: Escuta, 1995, p. 47.

${ }^{45}$ BENJAMIN, W. O Despertar do sexo. In Imagens de pensamento. Trad. João Barrento. Lisboa: Assírio \& Alvim, 2004, p. 121.

${ }^{46}$ BENJAMIN, W. Filatelia. In Imagens de pensamento. Lisboa: Assírio \& Alvim, 2004, p. 56.
} 
jovem e alegre mas tendo consciência do homem histórico, ${ }^{47}$ relações de força que marcam o político. Nestas relações de força atuam as intensidades ou forças demoníacas. Forças intensivas que abrem o político para fora da nomeada "soberania" - isso é um movimento ético. [O] aberto é aberto numa relação de forças intensivas; não se trata [d]o aberto do discurso "metafísico" da fala. A intensidade não é um "ser"; não tem seu passe pela "casa" do espírito [ou da repetição infernal do mesmo]. Antes de tudo é bicho[s] - pura intensidade [a natureza em sua alma] que se repete na diferença do mundo das coisas além do pensamento da representação. Em sua correspondência, ${ }^{48}$ Benjamin sugere a Scholem que o texto Rua de sentido único, ${ }^{49}$ de forma ainda tímida, daria o tom para as Passagens de Paris, este último, tentando dar a concretude extrema de uma civilização. Esta civilização burguesa estaria sujeita à destruição da aura pela vivência do choque: “... a sensação da modernidade: a destruição da aura na vivência do choque", ${ }^{50}$ o que seria recomendável, segundo Benjamin, retornar até Freud, "a explicação teórica não poderá prescindir das considerações de Freud em Para além do princípio do prazer". ${ }^{51}$ No além do princípio do prazer não se rege pelo prazer. O princípio de prazer reina sobre todas as coisas, mas não governa todas as coisas. "Não há exceção ao princípio, mas há um resíduo irredutível ao princípio um além..." ${ }^{52}$ Um além [...] que não é governado pela linguagem humana. A este caráter destrutivo está presente o instante da abertura do movimento destrutivo da pulsão de destruição. Este caráter destrutivo é o que resiste, que faz com que não se transformem as coisas em massa. Aqui, o mal-estar se centra na pulsão de morte. Ainda nesta civilização, descrevendo junto com Baudelaire, olhos dos quais se poderia dizer que perderam a faculdade de olhar, mas, dotados de pulsões. ${ }^{53} \mathrm{Ou}$ ainda sobre a força que não pode ser domada: "o pouco que restará da política irá debater-se penosamente sob a pressão da animalidade generalizada, e que os

${ }^{47}$ BENJAMIN, W. Le Caractère destructeur (1931). Trad. Rainer Rochlitz. In Oeuvres II, Paris: Gallimard, 2000, p. 330.

${ }^{48}$ SCHOLEM, G. \& BENJAMIN, W. Théologie et utopie. Correspondance 1933-1940. Traduit par Didier Renault \& Pierre Rusch. Paris: Editions de l'éclat, 2010.

${ }^{49}$ BENJAMIN, W. Imagens de pensamento. Lisboa: Assírio \& Alvim, 2004, p. 264.

${ }^{50}$ BENJAMIN, W. Sobre alguns motivos na obra de Baudelaire. In A Modernidade. Trad. João Barrento. Lisboa: Assírio \& Alvim, 2006, p. 148.

${ }^{51}$ BENJAMIN, W. A Modernidade. Lisboa: Assírio \& Alvim, 2006, p. 456.

${ }^{52}$ DELEUZE. G. O que é o instinto de morte? In Sacher-Masoch: o frio e o cruel. Trad. Jorge Bastos. Rio de Janeiro: JZE, 2009, p. 110.

${ }^{53}$ BENJAMIN, W. Sobre alguns motivos na obra de Baudelaire. In A Modernidade. Lisboa: Assírio \& Alvim, 2006, p. 144. 
governantes serão forçados a criarem um simulacro de ordem". ${ }^{54} \mathrm{E}$ mesmo se lembrarmos aqui de uma de suas hipóteses mais radicais: "o saber inconsciente dos animais", 55 o que o filósofo Jacques Derrida nomeará mais tarde de animot. O que demonstra, a impressão de Benjamin com os destinos das pulsões [intensidades ou forças demoníacas] e de um inconsciente pulsátil no caminho de uma história aberta, onde o novo seria possível, porque o futuro não é conhecido antecipadamente. A força de um ato não seria necessariamente carregada de otimismo, pelo contrário, poderia provocar resultados aterrorizantes. O caráter de terror e suas [des]conexões com a compulsão à repetição; o estranho terror no campo das intensidades pulsionais - a repetição, uma força demoníaca. Forças demoníacas da linguagem das coisas que disseminam em sua destrutividade a vida mortalista. Defesa contra a morte mítica ou violência mítica. Das pulsões [estado de excitação] para as intensidades históricas [verdadeiro estado de exceção] intensidades ou forças espectrais dos últimos escravizados; tem-se um mecanismo de repetição da diferença do pulsátil produzindo e forjando diferenças em sua repetição; fazer explodir a estrutura da nomeada "Casa" - caráter político das intensidades. Um dos rios do inferno pulsa na destruição das coisas nomeadas e totais - Freud \& Benjamin entremesclados movendo intensivamente o Inferno; ínfero que [des] habita os mortos que atravessam Aqueronte. Não existe habitação fixa - as coisas estão em seu movimento permanentemente mudando de lugar em busca de novas pastagens para os instintuais pulsionais do[s] bicho[s]. Há um nomadismo nestes acontecimentos. O psíquico já é excitabilidade entremesclada na história do terror e produção de sua terrível diferença.

\section{Experiência silenciosa}

Neste momento, seria importante registrar as marcas das forças demoníacas das pulsões do pensamento freudiano na dita "Filosofia da diferença". Destes pontos de contato entre o político e as intensidades, os estudos de Deleuze ${ }^{56}$ seriam importantes num movimento da repetição como um movimento ético que repete a diferença, repetindo várias vezes a expressão da diferença das pulsões

\footnotetext{
${ }^{54}$ BENJAMIN, W. Notas sobre os "Quadros Parisienses" de Baudelaire. In A Modernidade. Lisboa: Assírio \& Alvim, 2006, p. 197.

${ }^{55}$ BENJAMIN, W. Panorama imperial. In Imagens de pensamento. Lisboa: Assírio \& Alvim, 2004, p. 19.

${ }^{56}$ DELEUZE. G. Différence et répétition. Paris: PUF, 2008 [Diferença e repetição. Trad. Luiz Orlandi e Roberto Machado. Rio de Janeiro: Graal, 2006].
} 
[intensidades]. Aqui, a repetição e a diferença estão tão bem entremescladas uma na outra que não é possível dizer o que é primeiro; relação da repetição com a linguagem das coisas [as coisas retornam em sua diferença] - repetição libertadora - repetição como movimento pulsional, em oposição à representação, repetição afetada pela experiência da diferença; a verdadeira repetição é aquela que corresponde diretamente à experiência da diferença na liberdade [em busca da liberdade]. Não há afetos da ordem do discurso ["Filosofia rosa"] - as coisas passam pela experiência. Com o eterno retorno, Nietzsche não queria dizer outra coisa: a repetição do eterno retorno consiste em pensar a partir da diferença [animais instintuais de Zaratustra]; quem ou as coisas ou os bichos que descem da montanha abrem caminho com seu caráter destrutivo, uma ferida na ordem, quebra e fratura da estrutura - esquizo-coisa [Teatro do terror]. O "ser" [não-ser] nomeado psicótico é fora de si [Eu] - se há alguma loucura, ela está na própria natureza; "ser" é perder-se de si. Com a força da experiência do terror cria uma abertura na vida - criando mortificação na diferença. O que plasma a experiência do terror são os estilhaços instintuais pulsionais dos fragmentos. Por trás dos fragmentos há intensidades pulsando e relacionando-se entre si com outras. É porque a repetição difere por natureza da representação que o repetido não pode ser representação nem ser "ser" da representação; a maneira como as pulsões são necessariamente vividas, mundo interno das repetições no instinto de morte. O que retorna não é o Todo, o Mesmo, o Igual, a Identidade; as coisas que retornam tem caráter estrangeiro, inquietante, extremo, excessivo, demoníaco - as coisas que retornam são os bichos. "A roda no eterno retorno é ao mesmo tempo produção da repetição a partir da diferença e seleção da diferença a partir da repetição". ${ }^{57} \mathrm{O}$ eterno retorno exige intensidade e coloca seu excesso a cada instante. Se o eterno retorno está em relação com a experiência do instinto de morte é porque promove a destruição da representação; relaciona-se ao excessivo que [des]liga o diferente ao diferente [o caráter destrutivo organiza-se na diferença do estrangeiro]. Aqui, os bichos são excessos na destruição dos sistemas da representação. A experiência do eterno retorno é intensiva, "puramente intensiva". ${ }^{58}$ Que Nietzsche não tenha feito a

\footnotetext{
${ }^{57}$ Idem, p. 61.

58 Idem, p. 313.
} 
exposição do eterno retorno ${ }^{59}$ não impossibilita pensar a prática das coisas e dos instintos retornarem em sua repetição nos bichos instintuais do profeta Zaratustra. São estes bichos intensivos que "falam" a cada instante com a História e seu rompimento - abertura material. "Temos dentro de nós uma pluralidade de instintos." Deleuze registra um "mundo da intensidade" retorno é intensiva], diferenças de diferenças que se repercutem ao infinito, dando um destaque especial ao conceito de pulsão de morte no campo da Filosofia da diferença, que seria uma crítica ao estruturalismo; fazendo a diferença entre instinto de morte e pulsão de morte. ${ }^{62}$ Neste forjar da diferença existiria, no texto de Deleuze, uma passagem da pulsão de morte para o instinto de morte, um "pulo de gato" da Teoria Psicanalítica para a Filosofia. Este conceito não teria mais qualquer fundamentação na ordem da linguagem humana, mas estaria próximo das coisas [linguagem das coisas]. As coisas "falam" a linguagem dos impulsos interiores e dos desejos [instinto que faz (o) bicho resistir diante das representações]. Os instintos designam em geral condições de vida e de sobrevivência [aqui, pulsão de morte seria pulsão de vida] com o risco de se destruir a si mesmo [potência demoníaca]; descoberta de um “Além” [...] - nesse aspecto a repetição constitui por si mesma o jogo de nossa ruína e de nossa salvação [Rettung]. Aspecto libertador da repetição: a ideia de um instinto de morte dá à repetição um poder autônomo e imanente em que o terror e seu caráter destrutivo se misturam intimamente com o movimento da liberdade do bicho[s]. No pensamento freudiano, o assombroso ou as coisas que infundem terror é sua concepção da repetição na vida psíquica dominada por um modelo material na teoria das pulsões de morte. A esta linguagem das coisas e seu caráter destrutivo, a pulsão de morte assombra na repetição toda a força do diferente, criando e possibilitando um pensamento do diferente na Filosofia da diferença. Aqui, a diferença, se expressa também na Filosofia [da diferença] com uma força repetitiva dos ferozes bichos instintuais de Zaratustra, capazes de destruir com seu estranho instinto, mesmo que seja com uma contração aqui e ali, isto é, uma liberdade no nomeado mundo humano. O Zaratustra de Nietzsche, ao soltar os

\footnotetext{
59 "Meus amigos, sou quem ensina o eterno retorno. Isso significa: ensino que todas as coisas retornam eternamente e vós eternamente com elas, e que já exististes inúmeras vezes e todas as coisas convosco..." NIETZSCHE. F. Sabedoria para depois de amanhã. Trad. Karina Jannini. São Paulo: Martins Fontes, 2005, p. 160 - 161.

${ }^{60}$ Idem, p. 178 - 179.

${ }^{61}$ DELEUZE. G. Différence et répétition. Paris: PUF, 2008, p. 311.

${ }^{62}$ BIRMAN, J. Freud \& a filosofia. Rio de Janeiro: JZE, 2003, p. 73.
} 
animais, ao afirmar o pensamento do eterno retorno - ético ${ }^{63}$ - afirma a diferença dos animais instintuais. Uma tentativa de ler as artes e a psicanálise pelo lado das intensidades ou animalidade. Freud com a pulsão de morte instala a experiência silenciosa das intensidades no aparelho psíquico [alma]; Nietzsche com os animais [de Zaratustra] instala a animalidade no pensar. Importante seria registrar também, que Freud e Nietzsche não se excluem, como pregam em voz alta em seus discursos os autoproclamados "nietzscheanos" em sua exclusão representacional inconsciente [a História do longo erro é a História da representação inconsciente]. A experiência de instinto de morte não pode ser reduzido ao campo da linguagem humana e ao discurso filosófico dos afetos falados. Está para "além...". Freud e Nietzsche não se eliminam - entremesclam-se - instintualmente com seus animais ou seus fluxos de excitações destroem o pensamento da representação. Não há mais o nomeado "ser" no estilhaço barroco pelas forças demoníacas das pulsões. A experiência passa pelo outro sem face [outro do outro] - [os] bichos da criatura. Esta força da pulsão faz derreter e desaparecer uma imagem [imago] ou ordem da fala no instante de seu instinto [mundo de forças puras]. A estrutura da "Casa" é a presunção do humano diante das forças das figuras da natureza. Até as coisas tem seu terror.

\section{Cada artista é inspirado por um desses demônios}

Em seus primeiros anos de pensamento, Rimbaud se constitui em ato no silêncio atravessado em anjos [Silences traversés des Anges ${ }^{64}$ ]. "Je est un autre" [eu é outro] - explorado pelo discurso filosófico e encontrando sua imanência radical na experiência da psicanálise, faz com que este ato encontre o outro pulsional. $\mathrm{O}$ conceitual do poético faz com que a dita filosofia encontre em ato sua experiência da reflexão. A arte como criatividade e não o "Eu" como caroço da reflexão - singular experiência. As duas faces do ego [je e o mol] tornam-se discurso, visto que o silêncio não é da ordem da face. As coisas que a face reconhece são coisas nomeadas pela consciência racional. $O$ outro do outro passa [não]ser o Je que pulsionalmente está numa relação de forças com o moi. Momento que as coisas silenciosas da natureza relacionam-se com o outro [do outro]. $O$ discurso humanista

\footnotetext{
${ }^{63} \mathrm{MACHADO}$, R. Deleuze e literatura - trágico, de fora, linguagem. Notas do curso ministrado por Roberto Machado na UFRJ, 2006.

${ }^{64}$ RIMBAUD, A. Vogais. In Poetas franceses do século XIX. Trad. José Lino Grünewald. Rio de Janeiro: Nova Fronteira, 1991, p. 154 - 155.
} 
da "face" ou o humanismo do outro homem subordina-se aqui ao pensamento da representação submetendo este outro [do outro] num extermínio do nomeado "ser". A reflexão se abre numa natureza reflexionante do pensar numa intuição intelectual - a imediatez do conhecimento e a sua natureza intuitiva: aqui, o romantismo fundou sua teoria do conhecimento sobre o conceito de reflexão, por que ele garantia não apenas a imediatez do conhecimento, mas também uma infinitude singular no seu processo. ${ }^{65} \mathrm{Eu}=\mathrm{n}\left[\mathrm{ão}-\mathrm{e}[\mathrm{u}]^{66}\right.$ - proposição de toda ciência e arte, registrado por Novalis, assenta-se sobre o inconsciente [pulsional]. Neste raro instante - eu é outro da vida pulsional. O eu e o outro convivem lado a lado na subjetividade moderna. O eu não é soberano - não domina seu território. Quando se sai da referência ao "Eu” [representante humano] estamos fora do discurso das ciências humanas - presença silenciosa das pulsões e inconsciente; nesta dinâmica instintual pulsional, o registro da pulsão é articulado ao registro do outro, sob as formas da pulsão de vida e da pulsão de morte. ${ }^{67}$ Cada artista é inspirado por um desses demônios. A consciência imediata do pensar é estar-consciente-de-si e devido a sua imediatez é denominada intuição - o que na alma, o Eu = n[ão-]e[u] é da [des]ordem de um inconsciente pulsional instintual. Esta intuição que é produzida pela liberdade natural dos instintuais pulsionais é um ato de liberdade. Na verdade, o critério que está em jogo não é mais o critério do conhecimento mas o critério do [des]prazer - uma tradição trágica. Falar de “Eu” e/ou "não-eu” sem intensidades ou excitabilidades é falar de nada. A participação do demos se dá nas ruas da alma. Ou seja: o que no romantismo alemão, com Novalis e Schlegel, está para uma radical consciência-de-si pela intuição ou um conhecer intuitivo, está para a psicanálise, com Freud, de um [des]conhecer de um profundo e ruidoso silêncio na criatura em sua finitude. A crítica da arte das coisas mais estranhas como criatividade ou a questão de uma teoria da criatividade não é um problema do discurso filosófico. A arte é a experiência criativa do devir e seu caráter destrutivo, a experiência criativa da própria morte na vida. Só se cria se é eroticamente potente. Freud e Benjamin não foram educados na Filosofia. Este bloqueio inconsciente do pensamento da representação ou deste discurso localiza-se na representação. Afeta

\footnotetext{
${ }^{65}$ BENJAMIN, W. Le concept de critique esthétique dans le romantisme allemand (1920). Trad. Philippe Lacoue-Labarthe et Anne-Marie Lang. Paris: Flammarion, 2008, p. 51.

${ }^{66}$ NOVALIS. Fragmentos I e II. In Pólen: fragmentos, diálogos, monólogo. Trad. Rubens Rodrigues Torres Filho. São Paulo: lluminuras, 2009, p. 139.

${ }^{67}$ BIRMAN, J. Cadernos sobre o mal: agressividade, violência e crueldade. Rio de Janeiro: Civilização Brasileira, 2009, p. 51.
} 
na pós-modernidade os críticos auto-proclamados "nietzscheanos" [ou “spinozistas"]. Através da representação e, afinal de contas, através de sua mais elevada representação - a do representante. Até mesmo os “afetos” encontram-se “desafetados" pela ordem do discurso dos afetos e sua perda de experiência [Erfahrung]. A linguagem remete a ela própria - eliminando a experiência da[s] coisa[s]. Por outro lado, raramente um psicanalista, se sente impelido a problemática da arte como criatividade das coisas estranhas. ${ }^{68}$ Estas coisas vivem internamente e externamente na filosofia da história e na psicanálise - pulsa num trágico [barroco] da finitude. Tragédia e trágico são coisas diferentes. As coisas que [os] estranhos bicho[s] da criatura instintualmente seguem é este "além..." - pura repetição instintual das pulsões. Repetição como tentativa de [des]ligação para uma erogenização. Pulsão de morte [!] ${ }^{69}$ [linguagem das coisas] - expressando-se na experiência da criatividade e finitude do trágico. Na atualidade de seu mal-estar, a pulsão de morte não tem seu passe pela tragédia. A pulsão de morte passa pela finitude do barroco [trágico]. Forças demoníacas ${ }^{70}$ que no mesmo instante se originam no interior do corpo e são transmitidas ao aparelho psíquico [alma] - o obscuro e estranho material das pesquisas da psicanálise; relação dos processos instintuais de repetição com a diferença. "As expressões de uma compulsão à repetição singularizam em alto grau um caráter pulsional [instintual] (...) alguma força “demoníaca' em ação”. ${ }^{71}$ A pulsão de morte marca que a vida está pulsando a cada instante e que a mesma está em processo de destruição na morte; instintos que penetram em sua natureza mais profunda e terrível, infundindo terror e insistindo em irromper com seu caráter destrutivo. Isso que faz parte do silêncio ruidoso apresenta o terror. Estranhos casos de repetição, coisas que repetem coisas no

\footnotetext{
${ }^{68}$ FREUD, S. Lo ominoso (1919). Trad. José L. Etcheverry. In Obras Completas. Buenos Aires: Amorrortu, 2007, vol. 17, p. 219.

${ }^{69}$ O mundo encantado da Filosofia da "potência" representa-se pelos inúmeros casos de hostilidade frente à "pulsão de morte". De fato, extensivamente, um forte mal-estar do discurso filosófico frente às "pulsões sexuais" já demonstra esta problemática ao não trabalharem com seu caráter erótico. Pensamento da representação atravessado por sentimentos religiosos - os representantes da dita Filosofia da "potência" carregam a "peste emocional" moralizando o pensamento, excluindo este movimento [pulsão sexual e pulsão de morte]. Como registrou o próprio Freud: “....as criancinhas não gostam quando se coloca questões da inclinação inata do ser humano para o 'mal', a agressividade, destrutividade e também para crueldade". FREUD, El Malestar en la cultura, p. 116.

70 FREUD, S. Más allá del principio de placer (1920). Trad. José L. Etcheverry. In Obras Completas. Buenos Aires: Amorrortu, 2008, vol. 18, p. 35.

${ }^{71}$ Idem.
} 
trabalho da diferença na roda do eterno retorno; a vida pulsional [instintual ${ }^{72}$ servindo para ocasionar a morte; trata-se de instintos cuja função é garantir que o organismo seguirá seu próprio caminho para a morte; pressionando sempre e com caráter indomado ou não domesticado de uma força constante. "O que nos enuncia essa filosofia da vida, afinal? Nada mais nada menos que o organismo não suporta se manter vivo e quer morrer, pois pretende, no limite, se livrar de qualquer excitação"; mas "a filosofia da vida que sustenta o discurso freudiano seria eminentemente mortalista". ${ }^{73}$ Para a morte - assumir a finitude. Morte natural. Necessidade interna de morrer. O que existe por outro lado é a tentativa de domesticação dos bichos na criatura pela linguagem humana [“Casa humana”] paz de animais no pasto dos pastores. Mas, a questão principal e marginal: que as coisas vivas ou do mundo das coisas estão fadadas a morrer por alguma coisa interna. Aquilo ou a coisa que é dada no terror não é senão a morte. Fantasma da morte. "Fantasma de morte no interior da própria vida". ${ }^{74}$ Este instinto é um estranho - inquietante. $O$ fato é que estas forças instintuais procuram conduzir a vida para a morte desde o início da vida [biológica] da criatura. Forças instintuais das pulsões de morte que acontecem autonomamente ${ }^{75}$, expressando-se na vida com a morte. As coisas da natureza passando pela morte que aparece com o terror sob a foice fatal; guilhotina da morte na vida. Noite, terror, interior. É quando o sol desaparece e não acorda mais o Profeta; à sombra de um silêncio ruidoso as coisas emergem fraturando extensivamente. Assim como a terra - o corpo se rasga de dentro para fora. Na Floresta, bem longe, ouve-se um clamor na clareira em altas vozes. Os discípulos da estrutura consideram ainda a boca e teu Deus - porta-voz do Verbum. O tumultuoso silêncio da morte instintualmente no grande silêncio que há no mundo mergulhando na escuridão. Ao sabor do vento polenizador - l'art de mourir. Na morte aberta - onde o silencioso destrutivo ganha a doçura erótica dos seios. Na criatura - e morrer fosse só, na fonte muito escura, mas com a abertura do Angelus Novus. Aonde vai na escuridão. "Pouco depois, um Anjo, abrindo as portas

\footnotetext{
72 Idem, p. 39.

${ }^{73}$ BIRMAN. J. As Pulsões e seus destinos: do corporal ao psíquico. Rio de Janeiro: Civilização Brasileira, 2009, p. 84, 87.

74 Idem, p. 88.

${ }^{75}$ FREUD, S. El Malestar en la cultura (1929). Trad. José L. Etcheverry. In Obras Completas. Buenos Aires: Amorrortu, 2007, vol. 21, p. 113.
} 
/ Vem animar, alegre e com bondade / Os espelhos sem luz e as chamas mortas". ${ }^{76}$ É a morte que consola e alimenta a jornada - é o alvo desta vida. É o negro horizonte das forças demoníacas das pulsões desde o começo da vida sobre a terra. Superstições cíclicas sobre a morte. Não podemos pensar o fluxo das coisas de outro modo a não ser como a transição de um estado permanentemente morto para outro permanentemente morto.

Ah, chamamos o 'morto' de imóvel! Como se houvesse algo imóvel! O vivo não é uma oposição ao morto, mas um caso especial (...) Mal nasceis e já começais a morrer $^{77}$.

A cada instante esta ambivalência do bicho ou dos bichos da criatura podem irromper na vida para morte criando uma abertura material na História; a abertura se dá como pulsão como exigência de trabalho. Aqui, os instintuais pulsionais de morte criam uma abertura nas coisas nomeadas pela linguagem "humana". Os instantes instintuais de abertura estão próximos de uma natureza: inconsciente e pulsão de morte. Para a morte e com a morte numa filosofia da vida mortalista a cada instante que pulsa na linguagem das coisas. A linguagem é fruto da erotização dos acontecimentos dos corpos entremesclada na morte. Seria como se [um] bicho dissesse: - pegue seus botões de rosa enquanto pode / o tempo está voando / a estas horas, flores que hoje riem, amanhã estarão mortas. Mágica pela poesia - os poetas [não] estão mortos. A natureza e sua condição mágica. A natureza da[s] coisa[s] é natureza da coisa psíquica da natureza na história. Acontecimentos que rememoram Novalis e Schlegel em fragmentos como uma pequena obra de arte diria este pensamento no século XX: interpelação $d o[s]$ bicho[s] pelas coisas silenciosas e obscuras da natureza. Nada de "ser". Apenas bichos em seus estados de excesso em sua finitude natural com a morte. Trágico barroco da finitude. Num momento da dita "Filosofia da diferença", com o pensamento freudiano, Deleuze tenta trazer imanência a seu pensamento da diferença numa repetição mais profunda que se desenrola numa outra dimensão. O estado de excesso, isto é, a diferença intensificada, retorna a cada instante em sua repetição instintual mais estranha e silenciosa. Uma profundidade silenciosa ruidosa em que as intensidades

\footnotetext{
${ }^{76}$ BAUDELAIRE, C. A Morte dos amantes. In Antologia da poesia francesa. Rio de Janeiro: Record, 1999, p. 477.

77 “Vida após a morte. Quem tem razões para acreditar na sua 'vida após a morte' precisa aprender a suportar sua 'morte' durante a vida". NIETZSCHE. F. Sabedoria para depois de amanhã. Trad. Karina Jannini. São Paulo: Martins Fontes, 2005, p. 109, 122, 133.
} 
das coisas estão fora de um sistema de linguagem humana ou linguageiro [para além de uma leitura formalista da linguagem]. Este inconsciente intensivo é irredutível ao campo da linguagem humana. Os desejos fazem explodir as coisas nomeadas a cada instante em sua repetição do diferente na roda do eterno retorno, criando instintualmente a constante das intensidades. Alguma coisa não é governada [a Besta se agarra na alma e corpo]. Os bichos - caráter de terror - "a Besta" segura com força na alma e corpo, segundo o poeta. ${ }^{78} \mathrm{O}$ terror [em sua inquietante expressão] não é governado; as pulsões de destruição rompem fraturando o refinado biopoder. Na verdade, a criatura morreria se as intensidades fossem zeradas e governadas totalmente; a criatura mantém parte das excitações e descarrega parte das excitações.

\begin{abstract}
A tendência dominante da vida psíquica e, talvez, da vida nervosa em geral, é o esforço para reduzir, para manter constante ou para remover a tensão interna de estímulos, tendência que encontra expressão no princípio de prazer; esse fato constitui um de nossos mais fortes motivos para acreditar na existência de pulsões de morte ${ }^{79}$.
\end{abstract}

No estado de excesso, as coisas rompem em sua finitude com qualquer forma de representação; o excesso de intensidade é liberado, mas o instinto de morte não consegue ser completamente expulso da "Casa" - o estrangeiro permanece parasitando esta "cultura européia"; as coisas retornam em sua animalidade produzindo a diferença material [materialidade que se inscreve no psiquismo como um traço e na história rememorada - traço rememorado] e a destruição interna da linguagem humana ou da "Casa" onde habita o nomeado "ser". Neste caráter destrutivo das pulsões o silêncio é atravessado em Anjos. [A] pulsão de morte [silenciosa-barulhenta] atravessada no Anjo da história - destrói e ao mesmo tempo rememora os traços em cinzas. Esta magia envolve alma[s] e corpo[s]. ${ }^{80} \mathrm{O}$ silêncio da pulsão de morte perturba o silêncio de outra pulsão de morte - nessas perturbações ruidosas dos instintuais pulsionais de morte [des]habita $o[s]$ bicho[s] este movimento $d o[s]$ bicho[s] na criatura faz parte de um inconsciente pulsional. Esta magia pulsional toca o terror involuntário não domesticável. Anjo ou Mago - as forças pulsionais $d o[s]$ bicho[s] na criatura retornam à terra; retornando

\footnotetext{
${ }^{78}$ JARDIM, R. Sangradas escrituras. Brasília: Ed. do Autor, 2009, p. 542.

${ }^{79}$ FREUD, S. Más allá del principio de placer (1920). Trad. José L. Etcheverry. In Obras Completas. Buenos Aires: Amorrortu, 2008, vol. 18, p. 54.

${ }^{80}$ RIMBAUD, A. de: Poesias (Últimos versos) - LXXXIII. In Poetas franceses do século XIX. Trad. José Lino Grünewald. Rio de Janeiro: Nova Fronteira, 1991, p. 159.
} 
rememoradas pelo pólen disseminado pelo vento e [os] bicho[s]. Primeira lição: o melhor amigo do bicho - é o bicho[s]. Bicho[s] sem face. As forças obscuras e silenciosas do bicho[s] podem ser rememoradas em sua [in]finitude de seu ato pelo Angelus Novus. O imprevisível da finitude das excitabilidades da criatura está presente no instante da violência pura das intensidades que é constitutiva da experiência da vida do aparelho da alma; mas - com a [im]possibilidade de ser rememorada na abertura da História. As forças demoníacas das pulsões de morte projetam sua sombra silenciosa sobre o passado, e este, rememorado pelo Angelus Novus coloca suas forças em ato: fraturando e destruindo. A natureza à espera de um austero silêncio. ${ }^{81}$

\section{[a] coisa em ato na criança}

Aproveitei uma oportunidade que se me ofereceu durante os primeiros anos de vida de meu sobrinho, Benjamin ${ }^{82}$ - puro ato como trabalho de ligação. Na praia, construíamos castelos de areia e seus fragmentos corriam diante dos dedos das mãos ao tomar uma certa rigidez quando secos [cristalizado]. Benjamin, diante da cena, destruía o castelo. Destruição a cada instante [da representação]. A coisa em ato, misteriosa - repetia-se. Não há desconstrução neste momento e sim destruição ou um caráter destrutivo. A coisa repetia-se: ao construir o castelo, o mesmo era destruído com a pequena mão de Benjamin. A criança não passa inicialmente pela desconstrução - repete originariamente o caráter destrutivo em ato na produção da diferença. Nem mesmo existe face neste momento. Apenas o ato destrutivo e seu prazer de destruir intensificado no instante da destruição do ato. As intensidades estão presentes desde já. Intensidades das coisas. As coisas em ato como problemática da ligação [ligações ocultas]. Ou seja: a categoria do jogo [brincadeira] com coisas e como coisa em ato como que antecedendo ao pensamento e a linguagem fonemática. O jogo como pura intensificação do prazer - presente ou não [seu caráter destrutivo]. O perigo da criança para ordem política representacional enquanto ordem do campo do recalque. O jogo em ato não é uma fantasia e nem uma representação. Seu caráter é que ele é um ato. Uma coisa. Não tem seu passe originário pelo recalque campo da fantasia e representação. Nem mesmo o passe

\footnotetext{
${ }^{81}$ VIGNY, A. A Natureza está chamando... In Antologia da poesia francesa. Rio de Janeiro: Record, 1999 , p. 146.

${ }^{82}$ Benjamin Daniel Galvão.
} 
deste nomeado "ser" [fantasia e representação] inconsciente existe neste momento. O que existe como imanência intensiva é o jogo: a criança e suas intensidades como coisa em ato - a criança e os bichinhos. ${ }^{83}$ A criança, nos imemoriais tempos da humanidade, habita hoje em dia a casa da linguagem em sua manifestação mais violenta: a nomeada biopolítica [australiana] cruzada pela ética protestante [leia-se: cristã] numa política bioteológica a repetir o mesmo num modelo linguístico humano [nomeado humano]. Ou seja: a não anterioridade da repetição diferencial. Mas, a qualquer instante, silenciosamente, a coisa em ato, insurge-se na destruição das representações fonemáticas e imagéticas [linguagem humana] - demasiada humana. O inconsciente não é linguístico [não tem seu passe pela imago e fala] - é intensivo - um bicho[s] que silenciosamente se arrasta destruindo a cada instante representações onde habita o nomeado humano. "Jogo inocente sobre o qual não pesa nenhum passado". ${ }^{44}$ Isso, J. Derrida nomeia no discurso filosófico de animot, coisa que se arrasta silenciosamente, mas que a desconstrução enquanto pensamento não dá conta. Repetimos, aqui, o caráter destrutivo do jogo - a coisa em ato em suas [des]ligações para além do pensamento da representação e mesmo aquele que se diz libertário ou desconstrutivo.

\section{A Liberdade da vida sexual frente a moral sexual "civilizada"85}

Que é o corpo? Um corpo? Referência corporal? Uma experiência corporal de resistência? Antes de mais nada - este território é atravessado por intensidades pulsionais. É a forma mais antiga de resistências frente à nomeada "moral sexual civilizada". É expressão que se faz dançar como uma bailarina. É a natureza do sexual se manifestando a cada instante no ato do amor. Mas também é morte que se destrói ou a cada instante com seu caráter destrutivo encontra na morte sua finitude. Entre vida e morte - morte na vida - o corpo resiste com a alma num movimento pulsional de resistência. Mas que é esta intensidade[s] que claudica com seus fluxos esquizo e suas forças na abertura de um corpo livre em sua livre liberdade ou libertação da liberdade? - isto é, para um relacionamento livre com

\footnotetext{
${ }^{83}$ BARROS, M. Memórias inventadas: a infância. São Paulo: Planeta, 2003, [Manoel por Manoel].

${ }^{84}$ Olgária Chain Féres Matos [Carta de 3 de junho de 2012].

${ }^{85}$ A Liberdade da vida sexual frente a moral sexual "civilizada": [o] FEMEN como expressão social de resistência política na contemporaneidade. Trabalho apresentado no Colóquio Internacional Subjetividades e montagens corporais no mundo contemporâneo organizado pelo Programa de Pós-Graduação em Teoria Psicanalítica da UFRJ e pela Escola Doutoral da Universidade Paris VII (2013).
} 
suas forças. E aqui, estaríamos na questão da liberdade ou da libertação da liberdade e suas forças, fazendo referência ao movimento FEMEN ${ }^{86}$. Grupo de ativistas, cujo movimento nasce como expressão nas ruas da Ucrânia. Então, imaginem: um grupo de mulheres se reúne naquele frio da Ucrânia para fazer um manifesto com os seios de fora. "Nossos seios são nossas armas", declara [grita] o movimento. Agora, uma pergunta nos vem a mente: por que este movimento perturba ou provoca a ordem do discurso da nomeada "liberdade"? Se fôssemos realmente livres não haveria necessidade de falar sobre a "liberdade". Existe uma vida sexual que passa por uma repressão frente à conhecida "moral sexual “civilizada'”. Logo[s] - uma violência tal, que poderíamos registrar esta Gewalt como sendo da ordem da “linguagem humana” e suas cristalizações: da fala e das imagens arcaicas. Então, se é a presença [ausência] da imagem de um mito cristalizado em seu logos imemorial e que se manifesta na linguagem humana da fala - obviamente este peso deste discurso não está isento de uma moral: "moral sexual "civilizada"' frente à real liberdade. Acreditamos que o movimento de abertura para livre e real liberdade do corpo está entremesclada com o caráter destrutivo da alma quando esta é atravessada pela "moral sexual 'civilizada'”. Quando a alma é capturada por esta moral, entra em cena o corpo como possibilidade erógena de desejos e experiências e possibilidades de uma liberdade em ato - liberdade e liberdade[s] no prazer que se expressam no rompimento do corpo com seus estilhaços pulsionais e fragmentação destas forças que não podem ser domadas pela nomeada "civilização". Como expressão social frente - face - esta "cultura" ou de uma "moral sexual civilizada", acreditamos, no momento [instante], que o movimento social/político FEMEN, em nossa contemporaneidade, expressa ou tenta expressar esta "liberdade" da vida sexual - mesmo que numa cena teatral ou convulsivamente num espaço sagrado-sacralizado [ideologizado]. Poderíamos lembrar aqui de Camille Claudel, que quando desmonta a rigidez de um Rodin com suas esculturas de corpos velhos e fragmentados, estaria colocando a questão do “ser-para-a-morte". "Ser-para-a-morte" não da ordem da "linguagem falada" ou o que Walter Benjamin vai chamar de "linguagem humana"; "ser-para-a-morte" não da ordem do discurso filosófico da representação e da identidade; "ser-para-a-morte" não da ordem de um discurso psicanalítico [teológico] que fala em nome de "Freud"

\footnotetext{
${ }^{86}$ Estamos fazendo referência ao movimento FEMEN-Ucrânia [atualmente exilado em Paris].
} 
e que habita uma "Casa"... Mas, "ser- para-a-morte" de uma singularidade que carrega a finitude da criatura ou de um sujeito histórico; uma criatura fragmentada e seu corpo estilhaçado. O mesmo acontece com Sabina Spielrein e seu caráter convulsivo que destrói o pensamento da representação ou o discurso da "Casa". Se o espaço corpóreo na modernidade seria o local da extensiva liberdade e suas formas de vigilância, o espaço da alma seria o local das interdições inextensivas da moral sexual "civilizada" oculta. Corpo e alma andam de mãos dadas - com o prazer e a morte. Por isso, a expressão social do movimento FEMEN já seria uma expressão corporal de resistência que se manifesta principalmente nas ruas dos estados da alma. Então, não se trata aqui de defender o movimento FEMEN ou não... A questão, antes de mais nada, seria em sua diferença, tentar analisar este movimento como um movimento que carrega potencialmente partículas intensivas [des]ligadas a uma excitabilidade [irritabilidade] na Abertura de uma real liberdade. $O$ que este movimento tenta expressar a cada momento num instante eterno é exatamente a possibilidade de uma "liberdade" que não acaba e nem se cristaliza em imagens arcaicas e na linguagem como fala [linguagem humana]. É como se este movimento estivesse a cada instante fraturando em ato o discurso normativo da "Casa" ou de uma "moral sexual 'civilizada". Por outro lado, neste discurso, seria preciso um certo afastamento dos representantes desta "moral", o que poderíamos chamar de "trindade borromeana" [que não passa de um símbolo]: 1) Extermínio da libido e sua cristalização em imagens arcaicas; 2) a da ordem da fala numa posição "humana"; 3) e a estrutura em que estas duas primeiras habitam - a grande e infalível "Casa". Não há nada que este discurso "moral" odeie mais - isso - para não registrar sua hostilidade frente [a] “loucura”, [o] "feminino”, [o] "inconsciente”, a "sexualidade", [as] "pulsões sexuais" e suas forças... Mas, a característica mais saliente desse discurso é sua hostilidade em questão de "liberdade"... "Liberdade", que neste caso, seria a liberdade de uma vida sexual livre... "Libertação da liberdade" - que neste instante eterno se expressa para além das palavras e encontraà nas coisas a possibilidade de uma fratura. Resta saber se esta experiência corporal deste movimento dá conta de uma alma atravessada pela moral sexual "civilizada". O mal-estar é de [não] aparecer em ato frente à moral sexual "civilizada".

Retornamos ao trans aberto no desejo [de] ser trans plasmado por intensidades pulsionais - aí encontra-se [o] feminino, a loucura e a criança na fratura 
e destruição do mítico Patriarcado - e até mesmo a possibilidade de sua rememoração. O retorno para o inconsciente fracassa se não for experiência da manifestação da intensidade. A subversão desta força se torna um aspecto da redenção relacionada à verdadeira imanência do mundo - Angelus Novus carrega traços do anjo da Justiça como também do destruktiver Charakter.

\section{REFERÊNCIAS}

BARROS, M. Memórias inventadas: a infância. São Paulo: Planeta, 2003.

BAUDELAIRE, C. A Morte dos amantes. In Antologia da poesia francesa. Rio de Janeiro: Record, 1999.

BAUDELAIRE. C. Espanquemos os pobres! In Poesia e prosa. Trad. Aurélio Buarque de Holanda Ferreira. Rio de Janeiro: Nova Aguilar, 1995.

BENJAMIN, W. A Modernidade. Trad. João Barrento. Lisboa: Assírio \& Alvim, 2006.

BENJAMIN, W. Imagens de pensamento. Trad. João Barrento. Lisboa: Assírio \& Alvim, 2004.

BENJAMIN, W. Le Caractère destructeur (1931). Trad. Rainer Rochlitz. In Oeuvres II, Paris: Gallimard, 2000.

BENJAMIN, W. Le concept de critique esthétique dans le romantisme allemand (1920). Trad. Philippe Lacoue-Labarthe et Anne-Marie Lang. Paris: Flammarion, 2008 [O Conceito de crítica de arte no romantismo alemão. Trad. Márcio SeligmannSilva. São Paulo: lluminuras, 2002].

BENJAMIN, W. Sur le concept d'histoire (1940). Traduit Maurice de Gandillac. In Oeuvres III, Paris: Gallimard, 2000 [Sobre o conceito da história. In O Anjo da história. Trad. João Barrento. Lisboa: Assírio \& Alvim, 2010, vol. 4].

BENJAMIN, W. Sur le langage en général et sur le langage humain (1916). Traduit Maurice de Gandillac. In Oeuvres I, Paris: Gallimard, 2000.

BIRMAN. J. As Pulsões e seus destinos: do corporal ao psíquico. Rio de Janeiro: Civilização Brasileira, 2009.

BIRMAN, J. Cadernos sobre o mal: agressividade, violência e crueldade. Rio de Janeiro: Civilização Brasileira, 2009.

BIRMAN, J. Freud \& a Filosofia. Rio de Janeiro: JZE, 2003.

BIRMAN, J. Sujeito e estilo em psicanálise: sobre o indeterminismo da pulsão no discurso freudiano. In As Pulsões. São Paulo: Escuta, 1995. 
DELEUZE. G. Différence et répétition. Paris: PUF, 2008 [Diferença e repetição. Trad. Luiz Orlandi e Roberto Machado. Rio de Janeiro: Graal, 2006].

DELEUZE. G. O que é o instinto de morte? In Sacher-Masoch: o frio e o cruel. Trad. Jorge Bastos. Rio de Janeiro: JZE, 2009.

DOURADO, J. \& GALVÃO JR., JC. A Narradora. São Paulo: LiberArs, 2014 [Prelo].

FREUD, S. Carta 52 (1896). Fragmentos de la correspondencia con Fliess. Trad. José L. Etcheverry. In Obras Completas. Buenos Aires: Amorrortu, 2007, vol. 1.

FREUD, S. El Malestar en la cultura (1929). Trad. José L. Etcheverry. In Obras Completas. Buenos Aires: Amorrortu, 2007, vol. 21.

FREUD, S. Lo ominoso (1919). Trad. José L. Etcheverry. In Obras Completas. Buenos Aires: Amorrortu, 2007, vol. 17.

FREUD, S. Más allá del principio de placer (1920). Trad. José L. Etcheverry. In Obras Completas. Buenos Aires: Amorrortu, 2008, vol. 18.

FREUD, S. Proyecto de psicología (1895) Trad. José L. Etcheverry. In Obras Completas. Buenos Aires: Amorrortu, 2007, vol. 1.

FREUD, S. Una neurosis demoníaca en el siglo XVII (1922). Trad. José L. Etcheverry. In Obras Completas. Buenos Aires: Amorrortu, 2007, vol. 19.

GALVÃO JR., J.C. Sobre a «exceção humana» - Carta a Lacan, Jung, Schmitt... São Paulo: Liber Ars, 2012.

GOETHE, J.W. Fausto: uma tragédia. Trad. Jenny Klabin Segall. São Paulo: Ed. 34, 2011.

KAFKA, F. Carta ao pai. Trad. Modesto Carone. São Paulo: Companhia das Letras, 1997.

MACHADO, R. Deleuze e literatura - trágico, de fora, linguagem. Notas do curso ministrado por Roberto Machado na UFRJ, 2006.

NIETZSCHE. F. Sabedoria para depois de amanhã. Trad. Karina Jannini. São Paulo: Martins Fontes, 2005.

NOVALIS. A Cristandade ou a Europa. Trad. José Miranda Justo. Lisboa: Antígona, 2006.

NOVALIS. Pólen: fragmentos, diálogos, monólogo. Trad. Rubens Rodrigues Torres Filho. São Paulo: lluminuras, 2009.

RIMBAUD, A. de: Poesias (Últimos versos) - LXXXIII. In Poetas franceses do século XIX. Trad. José Lino Grünewald. Rio de Janeiro: Nova Fronteira, 1991.

RIMBAUD, A. Illuminations. Paris: Gallimard, 1999. 
RIMBAUD, A. Vogais. In Poetas franceses do século XIX. Trad. José Lino Grünewald. Rio de Janeiro: Nova Fronteira, 1991.

SCHOLEM, G. \& BENJAMIN, W. Théologie et utopie. Correspondance 19331940. Traduit par Didier Renault \& Pierre Rusch. Paris: Editions de l'éclat, 2010.

SPIELREIN, S. La Destruction comme cause du devenir (1912) Trad. Pierre Rusch. In Sabina Spielrein: entre Freud et Jung. Paris: Aubier, 1981, p. 213 - 262 [Die Destruktion als ursache des werdens. trad. livre de Renata Udler Cromberg USP].

VIGNY, A. A Natureza está chamando... In Antologia da poesia francesa. Rio de Janeiro: Record, 1999.

VIGNY, A. A Morte do lobo. In Poetas franceses do século XIX. Trad. José Lino Grünewald. Rio de Janeiro: Nova Fronteira, 1991. 